NBER WORKING PAPER SERIES

\title{
A STRATEGY FOR EVALUATING THE OPPORTUNITY COST OF TIME ESTIMATES FROM NEW CHOICE MARGINS
}

\author{
K.E. McConnell \\ Juha V. Siikamäki \\ V. Kerry Smith \\ Working Paper 23349 \\ http://www.nber.org/papers/w23349 \\ NATIONAL BUREAU OF ECONOMIC RESEARCH \\ 1050 Massachusetts Avenue \\ Cambridge, MA 02138 \\ April 2017
}

The authors declare that they have no relevant or material financial interests that relate to the research described in this paper. The initial analysis was conducted while they were consultants to the National Oceanic and Atmospheric Administration (NOAA) in the U.S. Department of Commerce thru NOAA's contracts with consulting firms during the period 2010 thru 2016. The preparation of the paper was not supported by these agreements. All data used in the analysis are in the public domain The views expressed herein are those of the authors and do not necessarily reflect the views of the National Bureau of Economic Research.

NBER working papers are circulated for discussion and comment purposes. They have not been peer-reviewed or been subject to the review by the NBER Board of Directors that accompanies official NBER publications.

(C) 2017 by K.E. McConnell, Juha V. Siikamäki, and V. Kerry Smith. All rights reserved. Short sections of text, not to exceed two paragraphs, may be quoted without explicit permission provided that full credit, including $(\odot$ notice, is given to the source. 
A Strategy for Evaluating the Opportunity Cost of Time Estimates from New Choice Margins

K.E. McConnell, Juha V. Siikamäki, and V. Kerry Smith

NBER Working Paper No. 23349

April 2017

JEL No. D13,D61,D83,E32

\begin{abstract}
Information frictions imply it is reasonable to expect the same commodity, in a given location, to sell for different prices at the same time. Aguiar and Hurst (AH) [2007] demonstrate how the search behavior implied by these price differences can be used estimate the opportunity cost of time. Their important insight allows the estimation of time prices over the lifecycle and the evaluation of the impacts of macro shocks on them. We provide the first assessment of the plausibility of this type of search behavior as a window on time prices. AH's measures of the opportunity cost of time are shadow values that are jointly determined with individuals' decision to search for bargains. Our analysis overcomes the challenges posed by this endogeneity by exploiting the complementarity between time and some types of market goods and services. We use changes in the expenditures for these goods in response to macro shocks as a basis for evaluating the $\mathrm{AH}$ choice margin. Using three different data sources we find that changes in expenditures on recreation related goods and services and time spent recreating are consistent with the AH framework's assessment of the impact of the Great Recession for the opportunity cost of time.

\author{
University of Maryland \\ College Park MD 20782 \\ tmcconn@umd.edu \\ Juha V. Siikamäki \\ Resources for the Future \\ 1616 P St NW \\ Washington DC 20036-1400 \\ juha@rff.org
}

K.E. McConnell

Department of Agricultural and Resource Economics

\author{
V. Kerry Smith \\ Department of Economics \\ W.P. Carey School of Business \\ P.O. Box 879801 \\ Arizona State University \\ Tempe, AZ 85287-9801 \\ and NBER \\ kerry.smith@asu.edu
}


A Strategy for Evaluating the Opportunity Cost of Time Estimates from New Choice Margins

\author{
K.E. McConnell, Juha Siikamäki, and V. Kerry Smith
}

\title{
1. Introduction
}

Over the past fifty years since Becker's [1965] seminal paper on the allocation of time, efforts to measure the opportunity cost of time and integrate the responses of these shadow values into the policy analyses in both micro- and macroeconomics have been extensive. The examples abound -- from models associated with labor supply decisions, household behavior, childcare decisions, health and environmental policies, and even the modeling of aggregate behavior over the business cycle. ${ }^{1}$ Indeed, it is probably not an exaggeration to suggest that the development of time use surveys around the world, including the American Time Use Survey (ATUS), was due to his contribution and the research it has stimulated.

Aguiar and Hurst (AH) [2007] have used Becker's insights to uncover a new margin of choice for valuing time. Given information frictions, it is reasonable to expect the same commodity, in a given location, may sell for different prices at the same time. ${ }^{2}$ As a result, these authors argue that each consumer's time spent shopping yields a return in the form of lower prices for the same goods, and these decisions about where and how much to search offer a "new

\footnotetext{
${ }^{1}$ The motivation and modeling of unemployment to employment transitions in a recent paper by Chodorow-Reich and Karabarbounis [2016] highlight the importance of measuring one of the components of the opportunity cost of time based on nonworking time. In their model it is a key part of understanding the pro-cyclical behavior of these costs. Further evidence of the importance of these issues in macro economics can be found in their use in the anlysis of structural transformation as economies develop. For example, Bridgman et al. [2017] document assemble information from time use srveys in 43 countries and find that as development increases share of share of time in household production declines.

${ }^{2}$ Stigler [1961] discussed the role of informational frictions in creating conditions where the same commodity could sell for different prices at the same time. Pratt, Wise, and Zeckhauser [1979] demonstrate the complex implications for judgments about market efficiency in the presence of search costs.
} 
margin" for estimating the opportunity cost of time. ${ }^{3}$ They assemble detailed information on how different groups search from two sources - ACNielsen's Homescan Panel and the ATUS. The former provides price information as well as the locations and frequency of shopping trips. The latter provides the length of time for each trip. A variety of models, including one that combines both data sources, allow AH to estimate the changes in the "price" of time over the life cycle. ${ }^{4}$ They observe that the opportunity cost rises by about 7 percent for those aged from mid-twenties through early thirties and declines after about 49 years of age.

Nevo and Wong [2015] have also used the AH model (and the same data sources) to estimate how the Great Recession affected the returns to shopping and, in turn, the opportunity cost of time. They found that during the period they attribute to the recession, between 20082010, the "price" of time declined by between 14 and 26 percent depending on the specific model used to implement the AH logic.

There are several advantages of the AH analysis of time spent in shopping activity. First, shopping activity captures a broad cross section of people. Most individuals shop. Compared with labor market decisions or modal choice in transport, there is little systematic selection in shopping data. Selection effects that influence our ability to recover information about the shadow value of time should be less prominent in shopping. Second, there are readily available data series containing decisions about time use and complementary expenditures that include information about individuals' demographic characteristics so we can investigate the cyclicality

\footnotetext{
${ }^{3}$ An independent proposal to exploit a different set of choices to estimate the opportunity costs of time was made by Phaneuf [2011]. He suggests that purchases of time-saving convenience goods reveal these time prices as well.

${ }^{4}$ The AH primary analysis relies on using the frequency of shopping trips to measure shopping time. Their preferred estimates from these models for the elasticity of price with respect to shopping time are between 7 and 10 percent reduction in price for a one percent change in time spent shopping (measured using frequency). When they use the American Time Use Survey reports for actual shopping time matched by demographic group to the Nielsen data the estimated elasticity would imply a 4 percent change. The authors are also careful to note that these estimates stem from comparing different demographic groups who behavior is being tracked for the same time period. See Aguiar and Hurst [2007] p. 1537 and their data appendix.
} 
of these shadow values for different groups. Finally, as we discuss at the close of the paper, the approach offers a new basis for evaluating proposals by Krueger, Kahneman, Schkade, Schwarz, and Stone [2009] to measure society's well-being based on 'time use and affective (emotional) experience".

While the empirical record largely supports the AH findings (see Aguiar et al. [2013] as an example), recent research by Petrosky-Nadeau, Wasmer and Zeng [2016] using the ATUS has identified some important new questions. These authors find that time spent comparing prices and products as recorded by the ATUS is extremely small on average and dominated by reports of zero time. Moreover, it displays very little variation over the cycle. Thus, the AH and Nevo and Wong results, as well as the Aguiar et al. [2013] confirmation, rely on interpreting the frequency of shopping and the total time shopping as the best measures for the search related activities that contribute to the return they measure in their price functions ${ }^{5}$.

The purpose of this paper is to propose a new strategy for evaluating the plausibility of the AH choice margin. We exploit the complementarity of time use with market goods and services and argue that we should observe the effects of changes in the opportunity cost of time displayed thru the expenditures on these goods. When the opportunity time cost of time is a large part of the implicit price that consumers "pay" to undertake an activity, then the goods and services used as part of that activity should change when we expect changes in the time price to increase or reduce the time intensive tasks outside the home. Since the opportunity cost is a shadow value, the only clear basis for evaluating the implications of changes in an endogenous

\footnotetext{
${ }^{5}$ Petrosky-Nadeau et al. conclude supporting the AH logic under the argument that the ATUS offers the best available information from a macro perspective and that more precise information is needed on shopping efforts from microeconomic data in consumer surveys. They find considerable heterogeneity in how individuals with different labor market participation patterns changed their shopping behavior in the recession, noting that: "Prior to December 2007 the unemployed and nonparticipants spent more time searching in the goods market than the employed. During the Great Recession, the unemployed drastically reduced their time searching for goods and services, spending the same amount of, or even less, time on this activity than the employed in 2012" (p. 53). These results further motivate our effort to provide separate confirmation of the logic underlying the AH choice margin.
} 
variable that are implied by the choices we are studying is to consider how both sets of variables respond to an exogenous shock. Macro shocks, such as the Great Recession, provide the potential for this type of test. Nevo and Wong used it to estimate the change in the shadow value of time and we use their results to frame our hypothesis for choices that should be jointly determined with the time allocations to shopping that allowed them to recover their estimates.

We provide direct evidence using this strategy by analyzing the money expenditures and time use for recreation-related activities in different time intervals around the recession. We use two key data sources (years in parentheses) - the Consumer Expenditure Survey (CE: 20012012) and the ATUS (2003-2012). We supplement this analysis with additional evidence based on a third source, Panel Study on Income Dynamics (PSID: 2005, 2007, 2009, 2011).. No doubt there are other activities besides outdoor recreation that might also serve to assess the AguiarHurst logic. Unfortunately, recreation is the only one where we have the prospect for direct observation of these types of complementary responses. That is, we can observe not only uses of time, but in addition there is sufficient resolution in the reporting of consumer expenditures to identify recreation-related expenditures. This requirement is important for a test of the effects of a macro shock because of what we know about how people used the time "freed-up" by the recession. Aguiar et al. [2013] note that two-thirds of the increase in leisure due to the decline in market work was absorbed by sleeping and watching TV, activities that can only be documented by reports in the ATUS. The next largest category, other leisure, accounts for 15 percent of the foregone market work time. ${ }^{6}$ There would be no expenditures that are complementary to sleeping and watching TV. Thus, changes in expenditures related to recreation, offer a unique opportunity to document how the recession-induced decline in the value of time can be confirmed. Our findings broadly support the potential for using the choice margin identified in

\footnotetext{
${ }^{6}$ Aguiar et al. p. 1679.
} 
Aguiar and Hurst's framework and highlight the importance of including Becker's full household production framework into the analysis of the shadow values for time.

We begin by summarizing the AH logic and the links between the opportunity cost of time and outdoor recreation. Then we describe our data sources and the organization of the expenditure and time reports to isolate the variation used to estimate the effects of the recessioninduced change in the price of time for recreation activities that have appreciable time costs. Finally, we present the results and discuss their implications

\section{Choice Margins and the Opportunity Cost of Time}

Aguiar and Hurst's [2007] proposal recognizes that informational frictions and the associated departures from a law of one price offer consumers an opportunity to find bargains by allocating time to shopping. Individual responses through this new and observable choice margin offer evidence of how different demographic groups value their time as well as how these values respond to external shocks. As we noted, Nevo and Wong's estimated decline in the price of time due to the Great Recession illustrates this second type of application.

We expect that activities that require significant time to "produce" the desired services will respond to changes in exogenous factors that change the shadow value of time. Our focus is on recreation activities. These activities typically entail trips to resource-based sites, where roughly 50 percent of the implicit price of the trip comes from the cost of time. ${ }^{7}$ As the NevoWong application confirmed, the AH framework implies the opportunity cost of time and thus the price of recreation trips will vary over the business cycle. While there is no centralized system to record these trips, the CE does track expenditures on specific activities, such as equipment for fishing, camping, etc.; lodging costs and rentals of large recreational equipment

\footnotetext{
${ }^{7}$ The original insight for the travel cost model dates to Harold Hotelling in 1947. For a review of the model and its many applications see Phaneuf and Smith [2005].
} 
such as campers, RVs, boats; and so forth. These types of expenditures are associated with different types of recreation trips. As a result, it is possible to document changes in complementary CE expenditures with sufficient resolution to conduct our proposed tests.

We assemble further supporting information from the ATUS for recreational time use and the expenditures complementary to recreation from the PSID. We report results from all three sources as part of our independent confirmation of the implications of the AH choice margin. The time allocations implied by their model are part of the broader logic in Becker's household production framework. Individual consumption in his model requires household production activities combining goods, services, and time. As a result, we can use changes in non-time related expenditures to confirm the behavioral responses expected when the opportunity cost of time changes due to exogenous shocks.

To demonstrate the role of value of time on recreational activities and complementary expenditures, we employ a model of the demand for recreation trips. These are trips to various locations away from home where the outdoor recreation takes place. Because they are away from the household's residence they entail travel costs. In general, we expect that recreation activity and expenditures will be directly proportional to the number of these trips. The recession lead to both job losses and reduction in the hours worked for those who remained employed. This translates into involuntary increases in non-work time and reductions in the opportunity cost of time for leisure related activities, such as outdoor recreation. Of course, to the extent earnings decline, there are also income effects.

We illustrate our proposed evaluation of the AH logic with a simple model of the demand for recreation trips . Let $Q_{i j t}$ designate the number of trips individual $i$ selects in period $t$ for recreation activity $j$. These trips are assumed to be influenced by the travel cost, $t c_{i j t}$ of a trip 
and the individual's income $m_{i t}$. The travel costs are defined to include the distance related travel costs, usually estimated as a price per mile traveled, and the time costs of the travel time for each trip.

Equation (1) is an example of this recreation demand model.

$$
Q_{i j t}=f\left(t c_{i j t}, m_{i t}\right)
$$

Macro-related events, such as the Great Recession, influencing the demand for labor enter the model thru changes in $t c_{i j t}$ the opportunity cost of time and thru changes in $m_{i t}$, income.

These impacts can be due to reductions in earnings and in other sources of income sensitive to the cycle. If we assume each recreation activity requires ancillary equipment as well as some specialized goods and services, then, controlling for income related effects, we can use the changes in expenditures to confirm the effects of the change in the opportunity cost of time.

More specifically, consider one type of ancillary equipment, designated as $E_{i j k t}$ for the $k$ th type of recreation related goods or equipment in period $t$. We can use changes in these expenditures to track the effects of changes in recreation trips. ${ }^{8}$ Assume the strongest form of complementarity to illustrate our argument, namely, $E_{i j k t}=a_{j k} \cdot Q_{i j t}$. In this case we expect that:

$$
\frac{d E_{i j k t}}{E_{j k t}}=a_{j k} \cdot \frac{d Q_{i j k t}}{Q_{i j k t}}=a_{j k} \cdot\left(\varepsilon_{t c} \cdot \frac{d t c_{i f t}}{t c_{i j t}}+\varepsilon_{m} \frac{d m_{i t}}{m_{i t}}\right)
$$

Where $a_{j k}=$ the spending on equipment $k$ for activity $j$ per trip

$$
\varepsilon_{t c}=\text { price }(\text { travel cost }) \text { elasticity of demand for trips }\left(\varepsilon_{t c}<0\right)
$$

\footnotetext{
${ }^{8} \mathrm{We}$ are assuming the macro related shock does not affect the price of these recreation goods and equipment. Under this condition the primary effect of the recession would associated with how reduction in income impact these recreation related expenditures. In the model some of the $a_{j k}^{\prime} s$ would be reduced. It could be argued that an inability to detect changes in recreation expenditures did not necessarily stem from offsetting prices and income effects on trips but instead a more involved mechanism with multiple sources for income effects. In the analysis of the PSID household level data below we use the state level unemployment rate as a control for these indirect effects and household specific employment variables for the influence of the opportunity cost of time.
} 


$$
\varepsilon_{m}=\text { income elasticity of demand for trips }\left(\varepsilon_{m}>0\right)
$$

We relate this demand for complementary expenditures to the empirical work on the demand for recreation through the shadow value (or opportunity cost) of time. The Nevo-Wong results suggest a 14 to 26 percent decline in the value of time due to the recession. With 50 percent of travel costs associated with time costs of a trip, this cycle-induced change in the time price means, for constant mileage related costs, a 7 to 13 percent decline in the price of a trip. The time price effect would, all else equal, be expected to increase trips. Using consensus estimates of the travel cost/price elasticity of demand $\left(\varepsilon_{t c}=-0.40\right.$ from Table 1 in Phaneuf and Smith [2005]), this price change means that, if we assume that nothing else changed, a 2.8 to 5 percent increase in the quantity demanded of outdoor recreation (often measured by trips in a given season). Of course, the recession affected incomes as well. Using either median or mean household income, the average impact was a 2 to 6 percent decline. ${ }^{9}$ The information to estimate the income elasticities for outdoor recreation is more "spotty" than the elasticity with respect to the implicit price and more dependent on the type of recreation activity being considered. Nonetheless, if we use a somewhat more speculative estimate for the income elasticity of 0.50 (also from Phaneuf and Smith), it implies income effects would result in an offsetting 1 to 3 percent decline in the quantity demanded of recreation. Overall then, based on the literature and Nevo and Wong's application of the AH framework, we would expect little discernable impact of the business cycle variations comparable in scale to the Great Recession. While this assessment is somewhat of a "back-of-the-envelope" calculation, large expenditure changes would call into question the size of the effects that Nevo and Wong's analysis attributes to the recession and bargain hunting as a mechanism for valuing time.

\footnotetext{
${ }^{9}$ See U.S. Census Bureau, Current Population Survey, General Social and Economic Supplements. See ftp://ftp2.census.gov/programs-surveys/cps/techdocs/cpsmar15.pdf
} 
Using the expenditure and time records for recreation in the ATUS and CE data series, we explore whether the implications of the AH and Nevo-Wang mechanisms can be indirectly documented thru the changes in the spending patterns for recreation related goods and services. We follow this analysis of state level averages with an analysis at the household level using the PSID measure of recreation related expenditures, which allow distinctions between aggregate measures of market effects and the recession-specific effects on employment at the household level.

\section{Data}

To evaluate this simple logic we assemble three datasets. The first is the CE Interview Survey. This survey collects expenditure information on major expense items using a three month recall period. It is collected quarterly with a rotating panel of respondents. Each household is interviewed in five consecutive quarters and each quarter $20 \%$ of sample consistent of new household. The quarterly target sample is 7,060 participating sample units, which are denoted "consumer units". A consumer unit is specified as follows: “(1) All members of a particular household who are related by blood, marriage, adoption, or other legal arrangements; (2) a person living alone or sharing a household with others or living as a roomer in a private home or lodging house or in permanent living quarters in a hotel or motel, but who is financially independent; or (3) two or more persons living together who use their incomes to make joint expenditure decisions." ${ }^{10}$ The sample for the Interview Survey is a national probability sample of households designed to be representative of the total U.S. civilian population (all civilian noninstitutional persons).

\footnotetext{
${ }^{10}$ http://www.bls.gov/cex/faq.htm\#q1
} 
In the interview, each household is asked about monthly expenditures using a detailed classification of expenditure items. In the initial interview, information is collected on demographic and family characteristics and on the consumer unit's inventory of major durable goods. Monthly expenditure data are collected in quarters 2-5 over a 12-month period. Income and employment information is collected in the second and fifth interviews.

The CE makes available data on a large number of detailed expenditure categories in the Public Use Microdata (PUMD). We examined the list of variables in the PUMD and selected expenditures data on the following categories for analysis

- boating,

- camping,

- hunting,

- fishing,

- rental of recreational vehicles, and

- lodging on trips away from home.

Table 1 lists the variables compiled, including the CE expenditure categories each variable represents.

We convert all expenditure data into 2012 dollars by using Price Indexes for Personal Consumption Expenditures by Major Type of Product and by Major Function, prepared by the U. S. Bureau of Economic Analysis. For each expenditure variable, we use the price index which most closely matches the type of expenditure in question. The last column in the table lists the deflators for each expenditure category.

Standard de-trending practices are not available with relatively short time series. As a result, there is always the potential to combine low frequency trends with business cycle 
variation. To avoid these issues, we follow Aguiar et al. and use state level variation in the business cycle to isolate the effects of the cycle. The variation across states provides a basis for controlling for common low frequency trends. Thus, our estimation strategy involves two levels of aggregation: first, compiling quarterly data on individual expenditures from the original monthly data, and second, compiling state-level estimates of quarterly expenditures, on average by year, by aggregating available individual quarterly observations by state and year. ${ }^{11}$ The CE does not include data for all states and all years. When a state has a small number of observations, the state identifier is excluded in the microdata. A balanced panel including data for all 12 years $2001-2012$ exists for 35 states. $^{12}$

The second data source we use is the ATUS, the same as Aguiar et al. This source is a randomly selected sample from the households that have completed their eighth and final month of interviews for the Current Population Survey (CPS). Completed diaries provide minute-byminute recordings of respondent's involvement in different activities. The diaries are coded into primary, secondary, and tertiary categories so that each activity is described consistently across different respondents. ATUS surveys categorize time-use data by using the following 17 primary categories:

\footnotetext{
${ }^{11}$ Note that although the $\mathrm{CE}$ is not intended to be representative at the state level, state-level estimates are unbiased in a repeated sampling sense (see http://www.bls.gov/cex/csxgeography.htm).

${ }^{12} \mathrm{Six}$ states produce an unbalanced panel. In the estimation, we have examined both balanced and unbalanced panels and found that the estimation results are robust to the estimation dataset.
} 
1. Personal Care

2. Household Activities

3. Caring For and Helping Household Members

4. Caring For and Helping Non-household

5. Working and Work-Related Activities

6. Education

7. Consumer Purchases

8. Professional and Personal Care Services

9. Household Services
10. Government Services and Civic

11. Eating and Drinking

12. Socializing, Relaxing, and Leisure

13. Sports, Exercise, and Recreation

14. Religious and Spiritual Activities

15. Volunteer Activities

16. Telephone Calls

17. Traveling

Each primary category comprises several second-tier subcategories, which are further divided into third-tier subcategories. When different activities by the same person are added together, they sum up to 1,440 minutes (24 hours). ${ }^{13}$ Half of the ATUS sample is elicited data on time use on weekend days (Saturday and Sunday) whereas the other half is collected data regarding weekdays.

We compiled data on the following five time use categories, which are specified in the ATUS and associated with outdoor recreation: hunting, fishing, boating, watersports, and walking. All these activities take place under the overall category 13: Sports, Exercise, and Recreation.

The survey recall period is 24 hours. Thus, the prospect that the respondent engaged in, for example, fishing or hunting is relatively low, even though many of individuals may participate in these activities during the course of a month or a year. As a result, we aggregate the time use data into three nested variables (listed from the most general to the most specific):

- $\quad$ All Recreation = boating + fishing + hunting + walking + watersports;

- Water Based Recreation = boating + fishing + watersports;

- $\quad$ Boating and Fishing $=$ boating + fishing.

\footnotetext{
${ }^{13}$ See Shelley [2005] for a description of the development of the current ATUS classification system.
} 
Figure 1 graphs recreation time use, on average per person, in each of the above three categories between 2003 and 2012 .

Based on the same logic we discussed for the CE data, we aggregate the data to the statelevel. Unlike the CE data, in which some states do not have data for each year, ATUS data includes observations for each year from each state. We examine the 48 states in the contiguous United States. Figure 2 confirms the diversity across states which is the argument for using state level differences to gauge business cycle effects graphs the state-level data by year for All Recreation, which is the most general recreation time use category. Similar to the CE data, the categories of time use typically entail trips away from home and hence are suitable for our analysis.

The third dataset, PSID, we use to evaluate whether the information in this panel supports the results from the CE and the ATUS. As noted earlier this allows the estimation of separate effects of market level variables, such as the state level unemployment rate, and household-specific indicators of changes in their labor market circumstances. The PSID is the longest running longitudinal household survey available anywhere in the world. ${ }^{14}$ The survey began in 1968 and has been conducted by the Survey Research Center (SRC) at the University of Michigan ever since. It collects data for roughly 5,000 households and 18,000 individuals. This survey is less representative than the CE or the ATUS, but it offers advantages because it is a panel that gathers considerable demographic information on individuals. Over time, the PSID has expanded, so that it now captures approximately the same expenditure categories as the CE. Andreski et al. [ 2014] find "that PSID expenditure data are largely consistent with CE data' (p. 135). They also find that total expenditures from PSID and CE vary with households' demographic characteristics in a similar way. One of our objectives in using the PSID data is to demonstrate that our

\footnotetext{
${ }^{14}$ Information on PSID is taken from: (i) PSID website: http://psidonline.isr.umich.edu/default.aspx; PSID questionnaires: http://psidonline.isr.umich.edu/Guide/documents.aspx and the PSID Main Interview User Manual: Release 2012.1. Institute for Social Research, University of Michigan, January 23, 2012.
} 
strategy for removing low frequency trends (i.e. by using state level aggregate measures of expenditures) displays a consistent record with what can be detected using individual expenditures. That is, we expect measures of the extent of labor force participation at the micro level to influence recreation-related expenditures in ways that are consistent with the CE and ATUS. These patterns would represent responses showing a decline in the value of time during recession.

The original PSID sample included 4,802 households and 18,192 persons. The sample was drawn from two separate independent samples:

(i) 1,872 low income families already included in the previous survey of the Survey of Economic Opportunity (the "SEO sample") and

(ii) 2,930 families selected by the SRC to form a nationally representative sample.

The PSID households can have both panel members and non-members. Each person included in the original sample as well as their direct descendants are members. Non-members live in the same household as the member but do not descend directly from the original sample. For example, individuals who have married an original member since 1968 are non-members. Note that the survey collects data on both members and non-members; the membership determines who possess the "PSID gene" which determines sample inclusion.

The PSID sample has experienced three major updates. First, the sample was refreshed to include immigrant families in 1990 by adding roughly 2,000 Latino households into the sample. Second, in 1997/1999, another 500 immigrant families were included into the sample, with a focus on addressing the non-Latino immigrants moving into the USA since 1968. Third, in 1997 the original sample of roughly 5,000 families had grown to approximately 8,500, and the sample was reduced to roughly 6,300 in 1997. 
The PSID was conducted annually for the period 1968-1997 but has been biannual since 1997. The survey collects data on all PSID families and all individuals in those families. The data are collected using personal interviews, primarily computer assisted telephone interviews. ${ }^{15}$

Starting in 2005, the expenditure module of the PSID has collected data on the family's annual expenditures on two categories relevant to our objectives, referred to as questions F90 and F91:

A) Trips and vacations, including transportation, accommodations, and recreational expenses on trips (F90), ${ }^{16}$

B) Recreation and entertainment, including tickets to movies, sporting events, and performing arts and hobbies, including exercise, bicycles, trailers, camping, photography, and reading materials (F91). ${ }^{17}$

Expenditures reported in response to question F91 are specified as expenses not already included in F90, so the expenditures measures are mutually exclusive. Of the two, F90, measuring trip and recreation expenditures, conforms more closely to outdoor recreation, the focus of our analysis and is the primary variable used for our reported results in the body of the paper. This expenditure category explicitly fits with our model of time costs as a determinant of expenditures.

We constructed a household-level panel data on the above expenditures across the four years of PSID data compiled in 2005-2011 $\left(2005,2007,2009\right.$, and 2011). ${ }^{18}$ Table $1 \mathrm{~A}$ in the appendix lists the means for questions F90 and F91 in the estimation dataset, including the mean conditional to the observation at non-zero and the overall sample mean, assumes that missing data denote zero. The table

${ }^{15}$ PSID Main Interview User Manual: Release 2013, http://psidonline.isr.umich.edu/data/Documentation/UserGuide2011.pdf.

${ }^{16}$ Question F90: "How much did you (and your family living there) spend altogether in 20XX on trips and vacations, including transportation, accommodations, and recreational expenses on trips?"

${ }^{17}$ Question F91: "How much did you (and your family living there) spend altogether in 20XX on recreation and entertainment, including tickets to movies, sporting events, and performing arts and hobbies including exercise, bicycles, trailers, camping, photography, and reading materials?--Do not include costs associated with the trips and vacations you mentioned previously."

${ }^{18}$ The PSID follows individuals who are linked back to the original 1968 PSID survey. The 1968 survey assigned each family a unique ID (the "PSID gene"). It is retained by each PSID-member, including individuals from the 1968 PSID survey and their direct descendants. Multiple households often share the same 1968 ID, so we used the birth year of the PSID member to identify the same household in the 2005, 2007, 2009, and 2011 surveys. In some cases, more than one PSID member has the same 1968 ID and birth year. This can happen, for example, in case of twins, or cousins of same age who share a common link to the original 1968 PSID household. We excluded each observation for which multiple PSID members had the same 1968 PSID gene and birth year. This enables us to uniquely link household-level data across the four years of interest $(2005,2007,2009$, and 2011). 
shows that that the means and conditional means are quite stable over time. The data in Table1A are in 2011 dollars.

We have a balanced panel comprising altogether 5,875 households ( $77 \%$ of all panel members). Overall, we have data from 7,633 households. In the econometric models, we examine models estimated using balanced and unbalanced panels. We convert expenditure data from the questions F90 and F91 to 2011 dollars by using the overall CPI as the deflator. Unlike with the CE data, where we are able to develop expenditure-specific deflators, the expenditure categories in the PSID data are so broad that a reliable assignment of the trip and other recreation expenditures to disaggregate CPI categories, such as sub-component price indexes for accommodation, or food, is not feasible. In addition to data on expenditure, we compile data on the characteristics of the household, including the age and employment status of the head of the household and the spouse, as well as the number of children.

\section{Empirical Models and Results}

We estimate multivariate panel-regression models that use macroeconomic indicators to provide signals of changes in the price of trips, income and wealth, to estimate their associations with recreation time use and expenditures. More specifically, in the models using statewide averages over time the state-level unemployment rates serves as our indicator of changes in the price of trips and household income and the housing prices index by the Federal Housing Administration, also at the state level, for the wealth effects due to housing. ${ }^{19}$

Our multivariate regression models are not structural relationships. Our analysis is a simple way to summarize the extent of correlation between the changes in recreation-related expenditures and changes in variables related to the time price of recreation and income and to

\footnotetext{
${ }^{19}$ Stroebel and Vavra [2015] explored the effects of wealth shocks on shopping activity and prices. For households who own their homes, the changes in value of that house are an important source for these wealth effects. They found that changes in housing prices do induce large changes in the local retail prices that these households paid for their goods and services. Their results suggest that wealth changes may also have an impact on behavior revealed through the AH shopping margin.
} 
control for wealth effects over the cycle. While it might be argued that changes in expenditures on goods and services that are large shares of a household's budget might have effects at the state level on employment and perhaps earnings, we believe this reverse causality is doubtful when the expenditure shares are so small.

We evaluate two primary models for each type of recreational expenditure from the CE and for each time category in the ATUS. Expenditure or time use by state $s$ and year $t$ is, designated by $Y_{s t}$. The first model is:

(3) $Y_{s t}-Y_{s t-1}=\alpha_{0}+\beta_{1}\left(U_{s t}-U_{s t-1}\right)+\beta_{2}\left(F H A_{s t}-F H A_{s t-1}\right)+\varepsilon_{s t}$

Where: $U_{s t}=$ the unemployment rate in state $s$ for year $t$ $F H A_{s t}=$ the FHA price index for housing in state $s$ and year $t$ The second model uses the same specification as (3) and includes state-level fixed effects.

We use the full sample periods available with the CE and ATUS to evaluate the effects of changes in macro-variables (unemployment, FHA housing price index) on the changes in expenditures for goods and services complementary to recreation trips. For the analysis of expenditures, we begin with a basic model that relates the median household income (in constant dollars) to the expenditures in each category.

We report a parallel analysis of time allocated to all recreation as defined above, waterbased recreation, and boating and fishing. In this case the time changes are analyzed separately for weekends and weekdays.

For the CE expenditure data, our sample includes two recessions: March 2001 (Q1) to November 2001 (Q4) and December 2007 (Q4) to June 2009 (Q2). The second recession offers an opportunity to conduct an analysis that is similar to Aguiar et al. by considering 2006-2007 in comparison to 2008-2010. Our second analysis focuses on this sub-period, where we restrict both 
the CE and ATUS to the period 2006 to 2010 and add dummy variables and interaction dummy variables with each independent variable to assess whether our measures for shocks have a differential effect in the Great Recession. ${ }^{20}$ The final set of results uses the PSID.

\section{A. Full Sample Analysis}

Table 2 provides the $\mathrm{CE}$ results for the full sample with each recreation expenditure category. The first row in each category is a simple expenditure/income equation with pooled cross sections of states. It confirms, as conventional theory would imply, that in general, the level of expenditures is positively related to income. One of the categories, hunting and fishing, yields a negative relationship. Some of these estimates for the effects of income (i.e. boating expenditures and the negative effect for hunting and fishing) are "marginally" significant. The negative effect of income on expenditures may seem surprising but likely reflects the selection effects arising from participation in the activity itself. That is, the median household income is a poor measure of the income for those who engage in hunting and fishing.

In the remaining categories we first report estimates for equation (3) and then add fixed effects for states. Only in the case of lodging do we find a negative and significant effect of the change in the unemployment rate on the first difference of expenditures. Otherwise, the logic is consistent with our expectations based on our interpretation of the likely time cost and income effects. That is, the average price effects on trips due to reduced opportunity cost of time are counterbalanced by the effects of reductions in income.

\footnotetext{
${ }^{20}$ There are differences across Nevo-Wong [2015], Aguiar et al. [2013] and Stroebel and Vavra [2015] in how the recession was defined. The NBER defines the contraction from December 2007 (Q4) (the peak) to June 2009 (Q2) (the trough). We considered all the various definitions. They do not alter our overall conclusions. The results are available on request.
} 
Table 3 reports the ATUS results for the model in (3) with the change in the time allocated to recreation activities. The dependent variable and the same independent variables are in first difference form with and without state level dummy variables. For the most part, the effects are limited to weekdays for all recreation. Increases in the unemployment rate should reduce the opportunity cost of time and therefore, holding income effects constant increase recreation. Since this effect "frees up" time on weekdays the increase in time on weekdays is consistent with this reasoning. Income decreases would be expected to be most pronounced in reducing the more "expensive" activities and likely accounts for the insignificant results with the disaggregate categories.

B. Analysis of the Sub-Samples

Tables 4 and 5 repeat the analyses reported in Tables 2 and 3 with two modifications. They reduce the sample to 2006-2010 so that it matches Aguiar et al. more closely. In addition, we include an interaction dummy identifying the Great Recession years as they do. Table 4 reports the expenditure changes and Table 5 the changes in time use.

These findings indicate significant wealth effects (through housing as reflected by change in the FHA housing price index) on expenditures for camping, hunting and fishing, and water sports. Declines in the FHA housing price index increase the expenditures on these activities, reflecting substitution away from more expensive recreation and these responses are accentuated by the Recession as we would expect.

The estimated effects of unemployment changes on changes in expenditures on water sports might at first seem quite different with statistically significant primary effect 
and interaction effect. Basically, the composite effect of the two terms for water sports is not significantly different from zero. Exclusion of the interaction term from the model yields the same insignificant effect. Finally, increases in the unemployment rate during the Great Recession reduced rental expenditures for boats, campers, etc. as one would expect. However, the effect is not robust in that inclusion of fixed effects alters both the size and statistical significance of the parameter estimate for the interaction term. Table 5's results suggest the estimates for time-use models parallel the full sample, with the coefficient on the recession-unemployment interaction being negative and insignificant.

\section{Analysis of PSID Household Level Recreation Expenditures}

Our empirical models developed using the PSID data supplement the primary results from the CE and ATUS analyses. We focus on the response of family expenses on trips and vacation (F90) and consider the role of two sets of variables: (a) aggregate indexes of labor and housing market conditions that are assumed to be relevant to each household based on its state of residence; and (b) household-specific measures of their working status in the panel year associated with each record. We also include the total household income. Our sample includes records for the panel from 2005 to 2011 . The basic model is estimated with a fixed effects estimator. A simple way of interpreting variables that vary across time as compared to those that vary by household or household and time is to describe a fixed effects estimator as being based on differencing the dependent and independent variables from their mean values, computed for each household over the years of the panel. This approach implies that the effects of the demographic variables are 
identified only when there are changes in the status described by a variable over time span in our panel. We will return to this issue below.

$$
Y_{i t}=\alpha_{0}+\beta_{1} U_{s(i) t}+\beta_{2} F H A_{s(i) t-1}+\sum_{j=1}^{K} \gamma_{j} Z_{j i t}+\varepsilon_{i t}
$$

Equation (4) defines our basic model with $Y_{i t}$ representing the expenditures on recreation trips and vacations, $U_{s(i) t}$ the unemployment rate for the state where the $i$ th panelist lives, and $F H A_{S(i) t-1}$ is the FHA housing price index assigned to the $i$ th panel is based on their state of residence, lagged one from the year of each panel record. The model also includes a set of terms, $Z_{j i t}$ which designates the $j$ th variable in year $t$ for each panel household. These include the labor market status variables (which are identified in this context by the transitions) the household income and the stochastic error, $\varepsilon_{i t}$.

Table 6 reports two models. Model (1) includes only the aggregate variables and household income assuming that the fixed effects estimator accounts for all panelistspecific effects. The aggregate unemployment rate and FHA price index variable are best interpreted as proxy measures for household expectations related to income changes and wealth changes due to state-level labor market or aggregate housing market changes. In this context, the overall effects hypothesized in our basic model are supported with this simple specification. Increases from the state-specific mean unemployment rate, across years in the panel, reduce household spending on recreation. Increases in the unemployment rate from the mean would be consistent with expectations for income reductions and would be expected to reduce recreation expenditures. This interpretation is different from the role of the unemployment rate with the state level averages for the $\mathrm{CE}$ and ATUS. With the PSID, we have direct measures of the employment status of the adult household members and can control for them directly. Thus the unemployment rate 
is likely capturing expectations about labor market conditions as a source for potential changes in the household's situation. Increases in the lagged FHA price index (compared to the average) would be consistent with increased perceived wealth and would all else equal be consistent with increases in recreation spending. The positive relationship to spending on vacations is also consistent with Stroebel and Vavra's [2015]. The contribution of the unemployment rate is significantly different from zero with a p-value less than 0.05 and wealth effect (i.e. the lagged FHA price index) is not significant, but has the anticipated sign.

Model (2) introduces the household level employment status variables. Our ability to detect these effects, using a within-estimate, relies on transitions. The lesson emerges is that the wife's employment status is the most important indicator of the effects of transitions. The Wald tests for excluding the set of labor market status variables, reflecting the wife as employed or unemployed (identified by the transitions in status over the panel), are significant at the 7 percent level. Both terms can be interpreted as reflecting income and substitution effects, with the sign of the working term indicating the influence of more discretionary income and the unemployed status a substitution effect, implying a lower opportunity cost of time for planning recreation trips. The household income term has a separate and significantly positive effect on spending, supporting our interpretation that the wife's labor market variable may be capturing the effect of discretionary income. The husband's employment status variables are not significant individually or considered in composite tests.

Overall, our results are supportive of the effects we argued explain the CE and ATUS findings. First, household income is a consistently significantly positive determinant of 
recreation expenditures. Second, when the household level labor market status variables are considered and their deviations from the panelist-specific mean evaluated over the time span of our study, the Wald test results for excluding them (i.e. the tests at the bottom of Table 6) reject the exclusion hypothesis for the status variables associated with the wife. Thus, taking account of these transitions from the mean labor market status and how they differ across panelists is important. Our hypothesis is that these changes affect the opportunity cost of time and discretionary income. These results hold up using a random effects estimate. However Hausman specification tests of the random effects versus fixed effects models do not support a random effects specification.

\section{Implications}

Aguiar and Hurst's [2007] paper proposed a new margin for measuring the heterogeneity in the opportunity cost of time across different types of individuals. Their analysis suggested the variation in this opportunity cost was substantial. Moreover, it changes in ways that were consistent with what we might have expected given the differences in demands on individuals at different stages in the life cycle. Nevo and Wong [2015] used their framework to estimate how the Great Recession affected these opportunity costs. They found a marked reduction. Their findings suggest a direct way to evaluate the plausibility of this new choice margin--namely use behaviors that are complementary to the time re-allocations underlying the estimates of this shadow value. We should be able to observe responses in these activities the endogenous reduction in the opportunity costs due to the Great Recession. Changes in the opportunity cost of time over the cycle, together with measures of changes in income and wealth variables, influence 
recreation related expenditures. Our expectation was that the composite effect would be negligible based on Nevo and Wong results and the past literature on recreation demand.

We organized three different data sources to evaluate whether measures of the expenditures and time allocated to outdoor recreation, as a set of complementary activities to the allocation of leisure time, support these conclusions. The majority of our analyses use panels of state-level aggregates to avoid confounding of low frequency trends with business cycle effects. First, we confirm a link between the average level of expenditures on these activities and median income at the state level. Next, we find clear support that the substitution and income effects of the recession are offsetting, as we argued would be implied by the composite insights of Nevo and Wong and measures of the income effects of the recession. Our estimates for the changes in consumer expenditures on recreation during a period with two recessions (i.e. 2001-20012) and for the more recent sub-period, 2006-2010, that includes the Great Recession, are consistent with our hypothesis. For the full period, we rely on the state level unemployment rate and the FHA price index to reflect macro influences. The first difference in expenditures for all the categories of recreation expenditures are generally not significantly affected by either variable. Only in the case of lodging expenditures do we find that the income effects of increases in unemployment appear to have an impact. This result is consistent with the basic structure of the model because we would expect income effects would also induce a substitution of lower cost forms of recreation -camping as opposed to overnight stays in motels or hotels - as part of composing these trips.

When we consider the sub-period, the first difference models including a recession interaction term for the unemployment rate and FHA price index do not display a significant effect for the recessionary period. That is, the primary coefficient and the interaction terms are 
offsetting and not significantly different from zero. In all other cases the coefficients are not statistically significant.

The changes in time allocations to recreation activities are also broadly consistent with our hypothesis. Only in the case of all recreation activities that take place on weekdays do we find a significant effect of the unemployment rate variable for the full sample period. Weekdays are when we would expect the primary influence of the substitution effect due to reduced opportunity costs of time to be present. The sub-period analysis of time use changes is also consistent with the implications of our adaptation of the $\mathrm{AH}$ and Nevo and Wong logic.

Finally, we considered a micro-panel analysis using the PSID panel. Here the transitions in the labor market status of household members provide what we are hypothesizing would be indicative of opportunity cost effects. We do not have a clear case for exogeneity in these labor market status measures at this micro-level so our analysis is more speculative. We include the aggregate unemployment rate and FHA price index variables as proxies for expectations. Controlling for variation in household income (from the household mean experience), it appears that the wife's labor market status variables captures changes in discretionary income over the cycle as it affects the household's recreation choices. There is some evidence of a potential substitution effect but it is not statistically significant.

Overall then, despite the endogeneity in measures of the shadow value of time, it is possible to use changes in the expenditures for complementary activities in response to the same exogenous shocks to evaluate the plausibility of the new choice margin proposed by Aguiar and Hurst. Our findings using recreation activities, the Nevo Wong estimates for changes in the opportunity cost of time, along with price and income elasticity measures from the existing literature on recreation demand, confirm the outcomes implied by the Great Recession. 
Becker's model for time allocation has had its primary impact in transforming how economic models describe income and substitution effects for individual and household choices. In his model a part of the prices of consumption choices may well be endogenous, due to the adjustments implied by altering household production decisions. As we noted at the outset, Krueger et al.'s [2009] proposal to use time use measures, along with expressive measures of personal wellbeing, as alternative gauges of the aggregate performance of an economy in meeting society's needs, is in direct contradiction to the Becker logic. It treats the time allocation as if it were separate from the assessment of personal wellbeing. Economists responding to their proposal, such as Nordhaus [2009] or Hurst [2009], have questioned the merits of this proposal arguing that these time allocations are part of an economic process resulting from optimizing decisions. In their view these measures are all endogenously determined. However, their argument is based on the maintained assumption of optimizing behavior. Since both outcomes the time allocations and the values - are jointly determined -how can we gauge the relevance of their critique outside of the structural model that frames it? Our strategy of using complementarity between time and consumption activities along with exogenous macro events offers an indirect basis for confirming the importance of their arguments and thus challenging the implicit assumptions underlying the national time accounting proposal. 
Table 1: Variables Constructed from the Consumer Expenditure Surveys 2001-2012

\begin{tabular}{|c|c|c|c|}
\hline VARIABLE & DESCRIPTION & $\begin{array}{c}\text { UNIVERSAL } \\
\text { CLASSIFICATION CODES } \\
\text { OF THE ORIGINAL CEX } \\
\text { VARIABLES INCLUDED* }\end{array}$ & $\begin{array}{l}\text { DEFLATOR } \\
(2001)^{* *}\end{array}$ \\
\hline Boating & $\begin{array}{l}\text { Outboard motor, boat with } \\
\text { a motor }\end{array}$ & $600110+600132$ & $\begin{array}{c}\text { PCE Recreational } \\
\text { Vehicles }\end{array}$ \\
\hline Camping & Camping equipment & 600410 & $\begin{array}{l}\text { PCE Sport } \\
\text { Equipment }\end{array}$ \\
\hline Hunting and Fishing & $\begin{array}{c}\text { Hunting and fishing } \\
\text { equipment }\end{array}$ & 600420 & $\begin{array}{l}\text { PCE Sport } \\
\text { Equipment }\end{array}$ \\
\hline Watersport & Water sports equipment & 600901 & $\begin{array}{l}\text { PCE Sport } \\
\text { Equipment }\end{array}$ \\
\hline Recreation spending & $\begin{array}{l}\text { Camping, hunting and } \\
\text { fishing, and watersport } \\
\text { expenditures combined }\end{array}$ & $\begin{array}{c}600110+600132+ \\
600410,600420+600901\end{array}$ & \\
\hline Lodging & $\begin{array}{l}\text { Lodging away from home } \\
\text { on trips }\end{array}$ & 210210 & $\begin{array}{c}\text { PCE } \\
\text { accommodations }\end{array}$ \\
\hline Rental & $\begin{array}{l}\text { Rental of boats, campers, } \\
\text { motor home, RV's, and } \\
\text { other vehicles on out of } \\
\text { town trips }\end{array}$ & $\begin{array}{c}620906+620909+ \\
620919+620921+ \\
620922\end{array}$ & $\begin{array}{c}\text { PCE Recreational } \\
\text { Vehicles }\end{array}$ \\
\hline $\begin{array}{l}\text { Total Discretionary } \\
\text { Spending }\end{array}$ & $\begin{array}{l}\text { Discretionary spending } \\
\text { without utilities }\end{array}$ & $\begin{array}{l}\text { Total expenditures - } \\
\text { housing - healthcare - } \\
\text { pension \& personal } \\
\text { insurance - utilities }\end{array}$ & \\
\hline \multicolumn{4}{|c|}{$\begin{array}{l}\text { * U.S. Department of Labor, Bureau of Labor Statistics, Consumer Expenditure Survey, Interview } \\
\text { Survey, 2001-2013 } \\
\text { ** U.S. Bureau of Economic Analysis, Price Indexes for Personal Consumption Expenditures by Major } \\
\text { Type of Product and by Major Function - Yearly (accessed October 12, 2014). }\end{array}$} \\
\hline
\end{tabular}


Table 2: Estimation Results Using Consumer Expenditure Survey Data (in \$2012, data for 20012012)

\begin{tabular}{|c|c|c|c|c|c|c|}
\hline EXPENDITURE CATEGORY & UNEMPLOY & NT RATE & $\begin{array}{l}\text { FHA HOU } \\
\text { IN }\end{array}$ & G PRICE & $\begin{array}{l}\text { HOUSEHOI } \\
\text { INC }\end{array}$ & $\begin{array}{l}\text { D MEDIAN } \\
\text { ME }\end{array}$ \\
\hline Boating & Estimate & $p$-value & Estimate & $p$-value & Estimate & p-value \\
\hline Cross-section & & & - & & 0.237 & 0.11 \\
\hline Cross-section & -1.071 & 0.07 & 0.003 & 0.81 & . & . \\
\hline First differenced & 0.137 & 0.91 & 0.045 & 0.23 & . & . \\
\hline First differenced and fixed effects & 0.062 & 0.96 & 0.041 & 0.29 & . & . \\
\hline Camping & Estimate & $p$-value & Estimate & $p$-value & Estimate & $p$-value \\
\hline Cross-section & & & . & & 0.021 & 0.02 \\
\hline Cross-section & 0.099 & 0.01 & 0.000 & 0.71 & . & . \\
\hline First differenced & 0.006 & 0.95 & 0.000 & 0.90 & . & . \\
\hline First differenced and fixed effects & 0.004 & 0.96 & -0.001 & 0.80 & . & . \\
\hline Hunting and fishing & Estimate & $p$-value & Estimate & $p$-value & Estimate & $p$-value \\
\hline Cross-section & & & . & & -0.100 & 0.08 \\
\hline Cross-section & 0.083 & 0.72 & -0.005 & 0.34 & . & . \\
\hline First differenced & -0.280 & 0.15 & -0.003 & 0.56 & . & . \\
\hline First differenced and fixed effects & -0.274 & 0.17 & -0.003 & 0.58 & . & . \\
\hline Watersports & Estimate & $p$-value & Estimate & $p$-value & Estimate & $p$-value \\
\hline Cross-section & & & . & & 0.043 & 0.00 \\
\hline Cross-section & -0.037 & 0.45 & 0.000 & 0.89 & . & . \\
\hline First differenced & -0.006 & 0.91 & 0.002 & 0.55 & . & . \\
\hline
\end{tabular}




\begin{tabular}{|c|c|c|c|c|c|c|}
\hline EXPENDITURE CATEGORY & \multicolumn{2}{|c|}{ UNEMPLOYMENT RATE } & \multicolumn{2}{|c|}{$\begin{array}{l}\text { FHA HOUSING PRICE } \\
\text { INDEX }\end{array}$} & \multicolumn{2}{|c|}{$\begin{array}{l}\text { HOUSEHOLD MEDIAN } \\
\text { INCOME }\end{array}$} \\
\hline & -0.021 & 0.09 & 0.000 & 0.50 & & . \\
\hline Rental expenditures & Estimate & $p$-value & Estimate & $p$-value & Estimate & $p$-value \\
\hline Cross-section & . & & - & - & 0.038 & 0.01 \\
\hline Cross-section & 0.082 & 0.13 & 0.001 & 0.63 & & . \\
\hline First differenced & 0.073 & 0.20 & -0.002 & 0.74 & & . \\
\hline First differenced and fixed effects & 0.076 & 0.18 & -0.002 & 0.74 & & . \\
\hline Lodging & Estimate & $p$-value & Estimate & $p$-value & Estimate & $p$-value \\
\hline Cross-section & . & & . & . & 1.117 & 0.00 \\
\hline Cross-section & 0.854 & 0.14 & 0.029 & 0.02 & & . \\
\hline First differenced & -4.821 & 0.00 & -0.029 & 0.25 & & . \\
\hline First differenced and fixed effects & -4.853 & 0.00 & -0.030 & 0.22 & & . \\
\hline
\end{tabular}


Table 3: Estimation Results Using American Time Use Survey (2003-2012)

\begin{tabular}{|c|r|r|r|r|}
\hline & \multicolumn{2}{|c|}{$\begin{array}{c}\text { UNEMPLOYMENT } \\
\text { RATE }\end{array}$} & \multicolumn{2}{c|}{ FHA HOUSING PRICE } \\
& INDEX \\
\cline { 2 - 5 } & ESTIMATE & P-VALUE & ESTIMATE & P-VALUE \\
\hline All Recreation Weekend & & & & \\
\hline First differenced & -0.052 & 0.182 & 0.000 & 0.986 \\
\hline First differenced and fixed effects & -0.051 & 0.189 & 0.000 & 0.914 \\
\hline All Recreation Weekdays & & & & \\
\hline First differenced & $\mathbf{0 . 0 4 5}$ & $\mathbf{0 . 0 9 6}$ & 0.001 & 0.308 \\
\hline First differenced and fixed effects & $\mathbf{0 . 0 4 5}$ & $\mathbf{0 . 0 8 9}$ & 0.001 & 0.308 \\
\hline Water Based Recreation Weekend & & & & \\
\hline First differenced & -0.013 & 0.566 & 0.001 & 0.532 \\
\hline First differenced and fixed effects & -0.014 & 0.557 & 0.001 & 0.465 \\
\hline Water Based Recreation Weekdays & & & & \\
\hline First differenced & 0.019 & 0.259 & 0.000 & 0.827 \\
\hline First differenced and fixed effects & 0.020 & 0.226 & 0.000 & 0.789 \\
\hline Boating and Fishing Weekend & & & & \\
\hline First differenced & 0.007 & 0.748 & 0.001 & 0.208 \\
\hline First differenced and fixed effects & 0.006 & 0.769 & 0.001 & 0.212 \\
\hline Boating and Fishing Weekdays & & & & \\
\hline First differenced & 0.017 & 0.219 & 0.000 & 0.603 \\
\hline First differenced and fixed effects & 0.018 & 0.201 & 0.000 & 0.744 \\
\hline
\end{tabular}


Table 4: Consumer Expenditure Survey Data 2006-2010, Including Interactions with the Recession Dummy 2008-2010

\begin{tabular}{|c|c|c|c|c|c|c|c|c|}
\hline EXPENDITURE CATEGORY & \multicolumn{4}{|c|}{ UNEMPLOYMENT RATE } & \multicolumn{4}{|c|}{ FHA HOUSING PRICE INDEX } \\
\hline & \multicolumn{2}{|c|}{ Main effect } & \multicolumn{2}{|c|}{$\begin{array}{l}\text { Recession } \\
\text { interaction }\end{array}$} & \multicolumn{2}{|c|}{ Main effect } & \multicolumn{2}{|c|}{$\begin{array}{l}\text { Recession } \\
\text { interaction }\end{array}$} \\
\hline Boating & Estimate & $\mathrm{p}$-value & Estimate & $\mathrm{p}$-value & Estimate & p-value & Estimate & $\mathrm{p}$-value \\
\hline First differenced & -10.94 & 0.32 & 11.10 & 0.36 & -0.97 & 0.23 & 0.99 & 0.22 \\
\hline First differenced $+\mathrm{FE}$ & -14.56 & 0.25 & 14.08 & 0.31 & -1.07 & 0.20 & 0.96 & 0.16 \\
\hline Camping & Estimate & $p$-value & Estimate & $p$-value & Estimate & $p$-value & Estimate & $p$-value \\
\hline First differenced & -1.25 & 0.13 & 1.23 & 0.15 & -0.06 & 0.05 & 0.06 & 0.08 \\
\hline First differenced $+\mathrm{FE}$ & -1.61 & 0.16 & 1.55 & 0.19 & -0.08 & 0.05 & 0.08 & 0.08 \\
\hline Hunting and fishing & Estimate & $p$-value & Estimate & $p$-value & Estimate & $p$-value & Estimate & $p$-value \\
\hline First differenced & -0.88 & 0.67 & 1.04 & 0.62 & -0.11 & 0.07 & 0.11 & 0.09 \\
\hline First differenced + FE & -0.82 & 0.70 & 0.97 & 0.66 & -0.13 & 0.04 & 0.12 & 0.05 \\
\hline Watersports & Estimate & $p$-value & Estimate & $p$-value & Estimate & $p$-value & Estimate & $p$-value \\
\hline First differenced & -2.64 & 0.06 & 2.64 & 0.07 & -0.06 & 0.05 & 0.06 & 0.06 \\
\hline First differenced $+\mathrm{FE}$ & -3.20 & 0.06 & 3.15 & 0.07 & -0.07 & 0.05 & 0.08 & 0.05 \\
\hline Rental expenditures & Estimate & $p$-value & Estimate & $p$-value & Estimate & $p$-value & Estimate & $p$-value \\
\hline First differenced & 1.53 & 0.11 & -1.59 & 0.10 & 0.01 & 0.59 & -0.01 & 0.69 \\
\hline First differenced + FE & 0.88 & 0.44 & -0.94 & 0.40 & -0.01 & 0.80 & 0.00 & 0.88 \\
\hline Lodging & Estimate & $p$-value & Estimate & $p$-value & Estimate & $p$-value & Estimate & $p$-value \\
\hline
\end{tabular}




\begin{tabular}{|c|c|c|c|c|c|c|c|c|}
\hline EXPENDITURE CATEGORY & \multicolumn{4}{|c|}{ UNEMPLOYMENT RATE } & \multicolumn{4}{|c|}{ FHA HOUSING PRICE INDEX } \\
\hline & Main effe & & Recession & & Main effe & & $\begin{array}{l}\text { Recession } \\
\text { interaction }\end{array}$ & \\
\hline First differenced & 8.44 & 0.64 & -14.64 & 0.43 & 0.26 & 0.43 & -0.34 & 0.34 \\
\hline First differenced + FE & 10.66 & 0.62 & -17.11 & 0.44 & 0.22 & 0.58 & -0.38 & 0.31 \\
\hline
\end{tabular}


Table 5: Estimation Results Using American Time Use Survey (2006-2010), Including Interactions with the Recession Dummy 2008-2010

\begin{tabular}{|c|c|c|c|c|c|c|c|c|}
\hline \multirow[b]{3}{*}{$\begin{array}{l}\text { All Recreation } \\
\text { Weekends }\end{array}$} & \multicolumn{4}{|c|}{ Unemployment } & \multicolumn{4}{|c|}{ FHA Index } \\
\hline & \multicolumn{2}{|c|}{ Main effect } & \multicolumn{2}{|c|}{ Recession interaction } & \multicolumn{2}{|c|}{ Main effect } & \multicolumn{2}{|c|}{ Recession interaction } \\
\hline & Estimate & $\mathrm{p}$-value & Estimate & $\mathrm{p}$-value & Estimate & p-value & Estimate & p-value \\
\hline DIFF & 0.012 & 0.976 & -0.127 & 0.760 & -0.006 & 0.452 & 0.008 & 0.370 \\
\hline $\begin{array}{l}\text { DIFF_FE } \\
\text { All Recreation } \\
\text { Weekdays }\end{array}$ & 0.120 & 0.831 & -0.241 & 0.680 & 0.001 & 0.940 & 0.007 & 0.488 \\
\hline DIFF & -0.089 & 0.776 & 0.180 & 0.575 & -0.009 & 0.132 & 0.012 & 0.055 \\
\hline $\begin{array}{l}\quad \text { DIFF_FE } \\
\text { Water Based } \\
\text { Recreation } \\
\text { Weekends }\end{array}$ & -0.251 & 0.503 & 0.347 & 0.369 & -0.007 & 0.411 & 0.012 & 0.103 \\
\hline DIFF & 0.182 & 0.590 & -0.253 & 0.464 & 0.003 & 0.656 & -0.002 & 0.794 \\
\hline $\begin{array}{l}\quad \text { DIFF_FE } \\
\text { Water Based } \\
\text { Recreation } \\
\text { Weedavs }\end{array}$ & 0.240 & 0.613 & -0.309 & 0.524 & 0.006 & 0.537 & -0.002 & 0.792 \\
\hline DIFF & 0.116 & 0.623 & -0.095 & 0.681 & -0.005 & 0.296 & 0.004 & 0.341 \\
\hline $\begin{array}{l}\text { DIFF_FE } \\
\text { Boating and } \\
\text { Fishing } \\
\text { Weekends }\end{array}$ & 0.027 & 0.921 & -0.005 & 0.986 & -0.006 & 0.333 & 0.005 & 0.296 \\
\hline DIFF & 0.123 & 0.649 & -0.154 & 0.585 & 0.004 & 0.453 & -0.005 & 0.355 \\
\hline DIFF_FE & 0.156 & 0.679 & -0.183 & 0.639 & 0.004 & 0.637 & -0.004 & 0.547 \\
\hline $\begin{array}{l}\text { Boating and } \\
\text { Fishing } \\
\text { Weekdays }\end{array}$ & & & & & & & & \\
\hline DIFF & 0.243 & 0.151 & -0.222 & 0.175 & -0.003 & 0.496 & 0.002 & 0.572 \\
\hline DIFF_FE & 0.165 & 0.395 & -0.140 & 0.457 & -0.005 & 0.396 & 0.004 & 0.418 \\
\hline
\end{tabular}


Table 6: PSID Fixed Effect Models for Expenditures for Trips and Vacations (F90) in 2011 Dollars 2011\$

\begin{tabular}{|c|c|c|}
\hline & Model 1 & Model 2 \\
\hline Independent Variable & \multirow{2}{*}{$\begin{array}{c}\text { Estimated Effect } \\
(\mathrm{t}-\mathrm{value})\end{array}$} & \multirow{2}{*}{$\begin{array}{c}\text { Estimated Effect } \\
\text { (t-value) }\end{array}$} \\
\hline & & \\
\hline \multirow[t]{2}{*}{ Unemployment Rate } & $-31.812 * *$ & $-28.712 *$ \\
\hline & $(-2.71)$ & $(-2.30)$ \\
\hline \multirow[t]{2}{*}{ FHA Housing Price Index lagged } & 0.594 & 0.607 \\
\hline & $(1.27)$ & $(1.30)$ \\
\hline \multirow[t]{2}{*}{ Total Household Income } & $0.0085 *$ & $0.0084 *$ \\
\hline & $(2.55)$ & $(2.49)$ \\
\hline \multirow[t]{2}{*}{ Employment status - head working } & & 66.152 \\
\hline & & $(0.82)$ \\
\hline \multirow[t]{2}{*}{ Employment status- head unemployed } & & -38.890 \\
\hline & & $(-0.48)$ \\
\hline \multirow[t]{2}{*}{ Employment status-wife working } & & $254.279 *$ \\
\hline & & $(2.22)$ \\
\hline \multirow[t]{2}{*}{ Employment status-wife unemployed } & & 208.056 \\
\hline & & $(1.40)$ \\
\hline \multirow[t]{2}{*}{ Constant } & $1038.351 * * *$ & $880.993 * * *$ \\
\hline & $(4.72)$ & $(4.17)$ \\
\hline $\mathrm{N}$ & 26382 & 26382 \\
\hline \multicolumn{3}{|l|}{ Test 1: All employment coefficients } \\
\hline $\mathrm{F}$ & & 1.85 \\
\hline Prob $>\mathrm{F}$ & & 0.1169 \\
\hline \multicolumn{3}{|l|}{ Test 2: Household head employment coefficients } \\
\hline $\mathrm{F}$ & & 1.67 \\
\hline Prob $>\mathrm{F}$ & & 0.1878 \\
\hline \multicolumn{3}{|l|}{ Test 2: Wife employment coefficients } \\
\hline 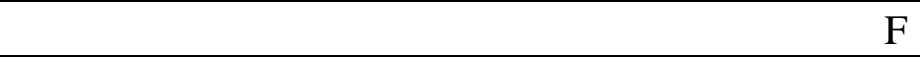 & & 2.66 \\
\hline Prob $>F$ & & 0.0702 \\
\hline
\end{tabular}




\section{References}

Aguiar, Mark and Erik Hurst, 2007. "Life-Cycle Prices and Production", American Economic Review, 97 (5): 1533-1559.

Aguiar, Mark, Erik Hurst, and Loukas Karabarbounis, 2013. “Time Use During the Great Recession”, American Economic Review, 103(5): 1664-1696.

Becker, Gary S. 1965. "A Theory of the Allocation of Time". The Economic Journal 75: 493517.

Benhabib, Jess, Richard Rogerson and Randall Wright. 1991. "Homework in Macroeconomics: Household Production and Aggregate Fluctuations", Journal of Political Economy, 99 (6): 1166-1187.

Bridgman, Benjamin, Georg Duernecker, and Berthold Herrendorf. 2017. "Structural Transformation, Marketization, and Household Production around the World", unpublished paper, Arizona State University, March

Chodorow-Reich, Gabriel and Loukas Karabarbounis.2016. "The Cyclicality of the Opportunity Cost of Employment”, Journal of Political Economy, 124 (6): 1563-1618.

Hurst, Erik.2009. "Thoughts on "National Time Accounting: The Currency of Life" “ in Measuring the Subjective Well-Being of Nations: National Accounts of Time Use and Well-Being edited by Alan B. Krueger (Chicago: University of Chicago Press for NBER) pp. 227-241.

Krueger, Alan B. Daniel Kahneman, David Schkade, Norbert Schwarz, and Andrew A. Stone. 2009. "National Time Accounting: The Currency of Life" in Measuring the Subjective Well-Being of Nations: National Accounts of Time Use and Well-Being edited by Alan B. Krueger (Chicago: University of Chicago Press for NBER) pp.9-83 
Loomis, John and Catherine Keske, 2012. "Did the Great Recession Reduce Visitor Spending and Willingness to Pay for Nature-Based Recreation? Evidence from 2006 and 2009”, Contemporary Economic Policy, 30 (2): 238-246.

Nevo, Aviv and Arlene Wong, 2015. "The Elasticity of Substitution Between Time and Market Goods: Evidence from the Great Recession", National Bureau of Economic Research, Working Paper 21318, July 2015.

Nordhaus, William.2009. "Measuring Real Income with Leisure and Household Production" in Measuring the Subjective Well-Being of Nations: National Accounts of Time Use and Well-Being edited by Alan B. Krueger (Chicago: University of Chicago Press for NBER) pp.125-144.

Petrosky-Nadeau, Nicolas, Etienne Wasmer, and Shutian Zeng. 2016. "Shopping Time" Economics Letters, 143:52-60.

Phaneuf, Daniel J., 2011. "Can Consumption of Convenience Products Reveal the Opportunity Cost of Time?" Economics Letters, 113:92-95.

Phaneuf, D. J., and V. Kerry Smith, 2005. Recreation Demand Models. In Handbook of Environmental Economics, Vol. 2, Valuing Environmental Changes, edited by K-G. Maler and J.F. Vincent. Amsterdam, Netherlands: North Holland, Chapter 15.

Pratt, John W., David A. Wise and Richard Zeckhauser, 1979. "Price Differences in Almost Competitive Markets", The Quarterly Journal of Economics, 93 (2): 189-211.

Rupert, Peter, Richard Rogerson, and Randall Wright. 1995. "Estimating Substitution Elasticities in Household Production Models." Economic Theory 6 (February): $179-93$. 
Shelley, Kristina. 2005. "Developing the American Time Use Survey Activity Classification System”, Monthly Labor Review, June 2015: 3-15.

Stigler, George, 1961. “The Economics of Information”, Journal of Political Economy, 69 (3): 213-225.

Stroebel, Johannes, and Joseph Vavra, 2015. "House Prices, Local Demand, and Retail Prices", SSRN. 